\title{
Effectiveness of self instructional module on knowledge of teachers regarding childhood attention deficit hyperactivity disorder
}

\author{
Mrs. Riya Anto ${ }^{1}$, Mrs. Vineetha Jacob ${ }^{2}$ \\ ${ }^{\text {I}}$ Dept. of Psychiatric Nursing, Yenepoya Nursing College/ Yenepoya University, India) \\ ${ }_{2}^{2}$ (Dept of Psychiatric Nursing, Yenepoya Nursing College/ Yenepoya University, India)
}

\begin{abstract}
Background: Attention Deficit Hyperactivity Disorder (ADHD) is the most common behavioral disorder in childhood which teachers have to face in regular schools. Early referral and effective management will help to prevent further complications in the adulthood. The aim of this study was to determine the effectiveness of self instructional module regarding childhood ADHD among school teachers. Method: Pre experimental (one group pre-test post-test) design was adopted for the study. Using convenient sampling technique fifty primary school teachers were selected. Data was collected using structured knowledge questionnaire on childhood ADHD. Results: The result showed that mean knowledge score of post test (22.44) was higher than the pre-test score (10.42) and the calculated value $(t=24.36)$ computed between pre-test and post-test was statistically significant $(p<0.05)$. Conclusion: The self instructional module was effective in improving the knowledge of teachers regarding childhood ADHD.
\end{abstract}

Keywords: Attention deficit hyperactivity disorder, School teachers, Self instructional module

\section{Introduction}

Childhood is referred to as the formative years of life because it is the stage during which most development occurs and skills are acquired. One of the common and important childhood disorders under study is Attention Deficit Hyperactivity Disorder (ADHD), formerly known as hyperkinetic syndrome of childhood or minimal brain dysfunction[1]. International data indicates a point prevalence of 3-7 \% of school-age children as probably having ADHD. This means that about one student in every classroom is affected with this disorder[2] Boys are more frequently referred and diagnosed than girls, with estimate range from $6 \%$ to $9 \%$ for boys and $2 \%$ to $3 \%$ for girls in than primary schools[3]. In India the prevalence of ADHD has been estimated as 10 to $20 \%$ [4].

Attention Deficit Hyperactivity Disorder is present from a very young age, continuing through childhood and adolescence and often into adulthood. Results of various studies show that over $50 \%$ children with this disorder will continue to show symptoms of inattention and impulsivity into young adulthood. [5]. Although there is no conclusive empirical evidence supporting the definitive causes of ADHD, there is considerable evidence suggesting a neural pathological impairment arising from a combination of genetic and environmental factors[6].

Children with ADHD are usually inattentive, impulsive and hyperactive. These children have a variety of school related problems including difficulty in paying attention, listening in the classroom and completing assignments [7]. Among the children with ADHD, 30 to 60\% have speech and language problems [8]. The impact of ADHD on society is enormous in terms of financial cost, stress to families, and interference with academic and vocational activities as well as negative effects on self esteem. Indian studies have shown that, ADHD was most common in first born children and those from a lower social class. Delayed development temper-tantrums, enuresis, tics, broken homes and psychiatric illness in parents were found common among children with this disorder [9]. Usually the problem is not recognized until the child enters the school [10]. It is difficult to identify the problem in children younger than four years because their behavior is much more variable than that of older children [11].

School is the unique setting for the early detection and effective management of ADHD. For children with ADHD to function successfully within the classroom setting, appropriate and efficient intervention strategies are required. Teachers need a broad knowledge about this condition in order to understand the needs of the children and to plan effective behavior modification strategies. Studies show that interventional programs promises an increase in knowledge of teachers regarding ADHD [12,13,14,] An improved awareness and understanding by the teachers allow for a better performance of these children in the classroom[6]. Success of these children largely resides in the hands of their teachers. This study was conducted with an aim to assess the knowledge level of teachers regarding ADHD and to provide them with a self-instructional module to help in the early detection and effective management of children with ADHD. 


\subsection{Study Design and sample}

\section{Materials and Methods}

An evaluative approach with one group pre-test post-test design was adopted for the study. Fifty primary school teachers, both male and female, from four schools of Mangalore were selected for the study. Purposive sampling technique was used to select the samples who met the inclusion criteria. Prior to the study formal written permission was taken from the schools selected for the study. Ethical clearance was obtained from ethics committee of Yenepoya University.

\subsection{Methodology}

The study design consisted of three phases. In the first phase of the study, a demographic proforma, a structured knowledge questionnaire and self instructional module (SIM) was prepared. Self instructional module contained information regarding causes, types, behavior exhibited by children, treatment and classroom management of ADHD. Validation of the tool and SIM was done by subject experts. Reliability was found using Karl Pearson Coefficient correlation and Spearman-Brown Prophecy formula. Reliability of the tool was found to be 0.91 . Second phase of the study consisted of pre-test, followed by administration of self instructional module. Prior to pre-test purpose of the study was explained to the teachers and consent was taken. Post-test was conducted on the eighth day of pre-test. In phase three, data analysis, hypothesis testing and interpretation of the result were done.

\subsection{Demographic Variables}

\section{Results}

The demographic characteristics of the subjects are given in Table 1

Table 1: Description of Demographic Characteristics of the Subjects

\begin{tabular}{lrr}
\hline Demographic Variables & Frequency & Percent $(\%)$ \\
\hline Age(in years) & 25 & 50 \\
$20-30$ & 12 & 24 \\
$31-40$ & 9 & 18 \\
$41-50$ & 4 & 8 \\
51 and above & 6 & 12 \\
Gender & 44 & 88 \\
Male & & \\
Female & 12 & 24 \\
Educational Status & 36 & 4 \\
TCH/D.Ed & 2 & 2 \\
B.Ed & 1 & 54 \\
M.Ed & 27 & 14 \\
Years of Experience & 7 & 30 \\
Less than one & 15 & \\
1-4 & & \\
6-10 & & \\
More than 10 & & 0 \\
Demographic Variables & 0 & 100 \\
& 50 & 82 \\
Training on ADHD & & \\
Yes & 9 & \\
No & 41 & \\
Management of student with ADHD & & \\
Yes & & \\
No & & \\
&
\end{tabular}

Table 1 shows the distribution of the subjects according to their demographic characteristics. Half of the subjects (50\%) were in the age group of 20-30 and only $8 \%$ were in the age group of 51 and above. The majority of the subjects were females (88\%), while $12 \%$ of them were males. Majority (72\%) of the subjects were with B.Ed qualification. Only $30 \%$ subjects had above 10 years experience and $2 \%$ had less than one year of experience. None of the subjects underwent training regarding childhood ADHD. Only $18 \%$ subjects had managed children with ADHD in the classroom. 


\subsection{Description of knowledge score}

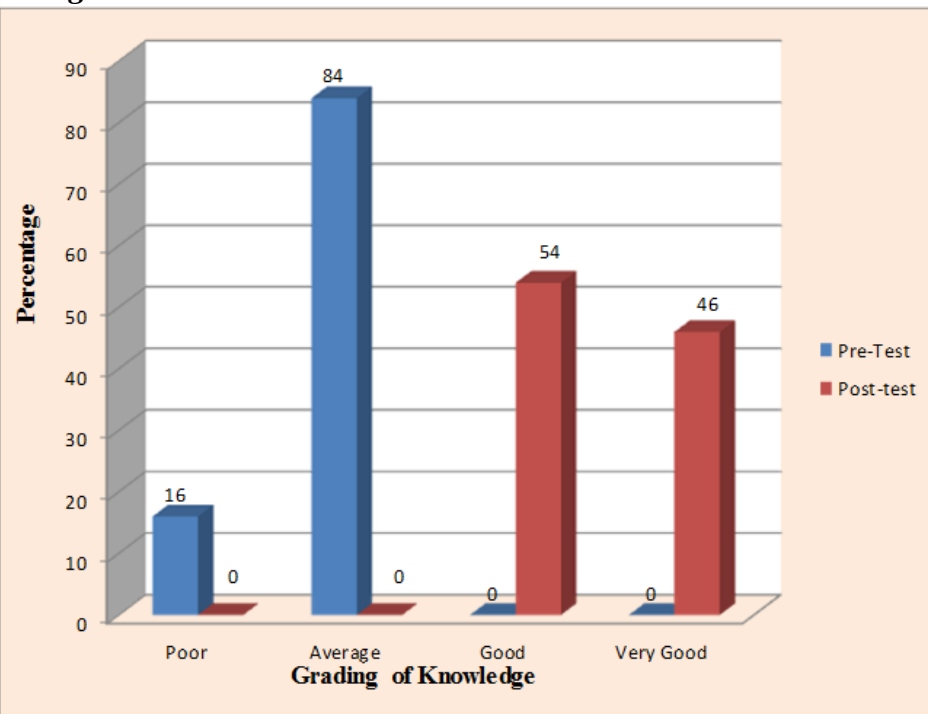

Fig. 1: Bar diagram showing the distribution of subjects according to the grade of the knowledge scores

The data presented in Fig.1 shows that in pre-test $16 \%$ of the subjects had poor knowledge, and $84 \%$ had average knowledge, whereas post test showed that $46 \%$ had good knowledge and more than half subjects (54\%) confirmed to have a very good knowledge.

\subsection{Effectiveness of self instructional module}

Table 2: Mean, Mean Difference, Standard Deviation and ' $t$ ' Value Between Pre-Test and Post-Test Knowledge Score.

\begin{tabular}{|c|c|c|c|c|c|c|}
\hline \multirow{2}{*}{ Group } & \multicolumn{2}{|c|}{ Mean } & \multirow{2}{*}{$\begin{array}{c}\text { Mean } \\
\text { difference }\end{array}$} & \multicolumn{2}{|c|}{ S.D. } & \multirow{2}{*}{ ' $\mathrm{t}$ ' value } \\
\hline & Pre test & Post test & & Pre test & Post test & \\
\hline $\begin{array}{c}\text { Primary } \\
\text { school teachers }\end{array}$ & 10.42 & 22.44 & 12.02 & 2.4 & 2.5 & $24.36^{*}$ \\
\hline
\end{tabular}

$\mathrm{t}_{(49)}=1.67$

* significant

Table 2 shows that the mean post-test knowledge score $(22.44 \pm 2.5)$ was greater than the mean pre-test score $(10.42 \pm 2.4)$. The calculated' $t$ ' value $(24.36)$ was greater than the table value $\left(\mathrm{t}_{49}=1.67, \mathrm{p}<0.05\right)$. This indicates that SIM was effective in increasing the knowledge of primary school teachers regarding childhood ADHD.

Table 3: Aspect Wise Paired 't' test Showing the Significant Difference of Pre-Test and Post- Test Knowledge Score Regarding Childhood ADHD among Primary School Teachers.

\begin{tabular}{|c|c|c|c|c|c|}
\hline \multirow[t]{2}{*}{ Aspects } & $\begin{array}{c}\text { Pre-test } \\
\text { knowledge } \\
\text { score }\end{array}$ & $\begin{array}{c}\text { Post-test } \\
\text { Knowledge } \\
\text { score }\end{array}$ & \multirow{2}{*}{$\overline{\mathbf{d}}$} & \multirow[t]{2}{*}{ SD } & \multirow[t]{2}{*}{ 't' value } \\
\hline & Mean & Mean & & & \\
\hline $\begin{array}{c}\text { General } \\
\text { Information }\end{array}$ & 1.36 & 3.04 & 1.68 & 0.71 & $16.73^{*}$ \\
\hline $\begin{array}{c}\text { Causes of } \\
\text { ADHD }\end{array}$ & 1.12 & 2.2 & 1.08 & 0.57 & $13.39^{*}$ \\
\hline $\begin{array}{l}\text { Symptoms } \\
\text { Of ADHD }\end{array}$ & 4.06 & 8.84 & 4.78 & 1.98 & $16.96^{*}$ \\
\hline Types of ADHD & 1.22 & 2.2 & 0.98 & 0.71 & $9.76^{*}$ \\
\hline $\begin{array}{l}\text { Management } \\
\text { Of ADHD }\end{array}$ & 2.66 & 6.16 & 3.5 & 1.43 & $17.31 *$ \\
\hline
\end{tabular}

$\mathrm{t}_{(49)}=1.67$

* Significant 
Table 3 shows that the mean post-test knowledge score was apparently higher than the mean pre-test knowledge scores in all the aspects. Knowledge score in each area was found to be statistically significant. The calculated $t$ value of all the aspects (general information on ADHD ( $t=16.73$ ), causes ( $t=13.39$ ), symptoms $(\mathrm{t}=16.96)$, types $(\mathrm{t}=9.76)$ and management of $\mathrm{ADHD}(\mathrm{t}=17.31)$ were higher than the table value $(\mathrm{t} 49=1.67)$ showing that the self instructional module on childhood ADHD was effective in increasing the knowledge of primary school teachers.

\subsection{Association between pre-test knowledge score and selected demographic variables}

There was no association between pre-test knowledge score and selected demographic variable. The pre-test knowledge score was independent of all variables like age $\left(\chi^{2}=4.8, \mathrm{P}=7.82\right)$, gender $\left(\chi^{2}=0.05, \mathrm{P}\right.$ $=3.841)$, educational status $\left(\chi^{2}=1.97, \mathrm{P}=5.99\right)$, years of experience $\left(\chi^{2}=1.22, \mathrm{P}=7.82\right)$, management of student with $\operatorname{ADHD}\left(\chi^{2}=0.2, \mathrm{P}=3.841\right)$.

\section{Discussion}

The result of the present study indicates that SIM was effective in increasing the knowledge of primary school teacher regarding childhood ADHD. The findings are consistent with the report of the study conducted in Pakistan on teachers' knowledge about ADHD week long training program for 49 teachers. The difference in mean score was $1.48+/-2.95$, and was statistically significant $(\mathrm{p}<.005)$ [12]. Other studies conducted by giving workshop and in-service training program also had reported an effectiveness of these programs on increasing teacher's knowledge in ADHD [13,14].

\section{Conclusion}

The present study shows that administration of self instructional module helps the teachers to improve their knowledge on various aspects and classroom management of ADHD. It is very urgent and essential today to implement this at school level to help children to excel in their future. This study has a great implication in nursing practice, education, research and administration. The result of the study shows the great need for the health personnel to educate the teachers regarding prevention and promotion of mental health in children. Use of pre experimental design and small sample size of course imposes limits to generalization of the result. The study can be replicated with larger sample size and experimental design.

\section{Acknowledgement}

Acknowledge all the participants for their participation and cooperation extended for the study and Principals of the schools and Yenepoya University administrators for giving permission to conduct the study.

\section{References}

[1]. S. Ameratunga, K Appleton, R Austin, N Baker, D Bunting and P Clark, NewZealand guidelines for the assessment and treatment of attention deficit/hyperactivity disorder, Report No: ISBN 0-478-26175-6, Wellington:Ministry of Health(NewZealand); 2001, 25

[2]. JE Mash and RA Barkely, Treatment of Childhood Disorders (NewYork: Guilford Publication, 2006).

[3]. SE Kleynhas, Primary school teacher's knowledge and misperceptions of attention deficit/hyperactivity disorder, Med Psych thesis, University of Stellenbosch, 2005, Available from:irl.sun.ac.za/bbitstream/ handle/10019.1/1612.Klenh,pdf?Sequence.

[4]. MS Bhatia, VR Nigam, N Bohra and SC Malik, Attention deficit disorder with hyperactivity among pediatric outpatients, $J$ Child Psychol Psychiatry 32(1), 1991,297-306

[5]. RA Barkley, Factsheet on attention deficit hyperactivity disorder [Internet] 2006,[cited on 2012Jan 10]. Available from: http://oppositionaldefiantdisorderx.org.

[6]. EK Murray, Don't give up on them: managing attention deficit hyperactivity disorder in schools-what teachers and parents believe and know, Doctoral thesis, Mudroch University, 2009. Available from: studia.ubbcluj.ro/download/pdf/611.pdf

[7]. BJ Sadock, VA Sadock and Ruiz P. Comprehensive textbook of psychiatry(Philadelphia:Williams and Wilkins,2009).

[8]. EJ Mash and DA Wolf, Abnormal child psychology (US: Wadsworth Publishers, 2010).

[9]. S Mehta, Implementation of climb up-ADHD, a multimodel peer mediated intervention for attention deficit hyperactivity disorder in children attending a large school in Najibabad, UP, 2007 [Updated 2012; cited 2012 Mar 24], Available from: http://helpusclimbup.org/

[10]. P Kaur, BS Chavan, S Lata, A Kaur, S Tinku and Y Arora Early intervention in developmental delay, Indian J of Paediatrics, 73(5) $2006,405-408$

[11]. MC Townsend, Psychiatric Mental Health Nursing: concepts of care in evidence-based practice (New Delhi: Jaypee Publishers,2007)

[12]. EU Syed and SA Hussein, Increase in teacher's knowledge about ADHD after a week-long training program a pilot study, $J$ Atten Disod,13(4), 2010, 420-423

[13]. JM Kos, Primary school teacher's knowledge, attitudes and behaviors toward children with attention deficit/hyperactivity disorder,DoctoralThesis,RMIT University, 2004, Available from: works.bepress.com/cgi/viewcontent.cgi?article=1008...Julie kos.

[14]. ME Niznik, An exploratory study of the implementation and teacher outcomes of a program to train elementary educators about $A D H D$ in the schools, Doctoral Thesis,University of Texas, Austin, 2004, Available from:repositories.lib.utexas.edu/bitstream/handle/.../niznikd24758.pdf?...2. 